\title{
Constructing Employability Indicators for Enhancing the Effectiveness of Engineering Education for the Solar Industry
}

\author{
Chin-Guo Kuo, ${ }^{1}$ Chi-Cheng Chang, ${ }^{2}$ and Chun-Cheng Huang ${ }^{3}$ \\ ${ }^{1}$ Department of Industrial Education, National Taiwan Normal University, No. 162, Sec. 1, Ho-Ping East Road, Taipei 106, Taiwan \\ ${ }^{2}$ Department of Information Management, Lunghwa University of Science and Technology, No. 300, Sec. 1, \\ Wanshou Road, Guishan, Taoyuan County 333, Taiwan \\ ${ }^{3}$ Taipei Municipal Nangang Vocational High School, No. 29, Xingzhong Road, Taipei 115, Taiwan
}

Correspondence should be addressed to Chi-Cheng Chang; chig@mail.lhu.edu.tw

Received 10 April 2014; Accepted 8 May 2014; Published 30 June 2014

Academic Editor: Ho Chang

Copyright (C) 2014 Chin-Guo Kuo et al. This is an open access article distributed under the Creative Commons Attribution License, which permits unrestricted use, distribution, and reproduction in any medium, provided the original work is properly cited.

\begin{abstract}
The aim of this research is to establish a set of employability indicators that capture the competency requirements and performance expectations that solar energy enterprises have of their employees. In the qualitative component of the study, 12 administrators and 32 engineers in the industry were interviewed, and meetings with focus groups were conducted to formulate a questionnaire for a survey of Taiwanese solar energy companies for the confirmation and prioritisation of the employability indicators. On the basis of the results of the quantitative component, an interpretational model relating competence, job performance, working attitude, and employability for solar corporation recruitment and training purposes as well as for school curricular development was developed. The interpretation model formulated effectively interprets the relationship between solar enterprises' expectations and students' employability. The research contributes a framework for the selection and cultivation of talent, as well as providing a basis for fundamental development of the solar engineering curriculum.
\end{abstract}

\section{Introduction}

The study of employability is a field of complex nature about which questions are often raised, questions for which there is not at all times a clear and definitive answer [1]. As pointed out by many researchers, employability is closely related to the competence and performance possibilities demonstrated by individuals [2-4]. Its ultimate measure is the contribution to the performance of an enterprise by the employee where the said performance is the output or production results of the enterprise. When the employee commands the competence required by the enterprise then it can be expected that the employee will demonstrate the performance anticipated by the enterprise [5]. Such competence can be broken down into four types: core competence, professional competency, management competence, and general competence [6]. In addition, the common core competences needed by staff of all departments of an enterprise could include customer orientation, teamwork cooperation, profession orientation, active aggressiveness, and performance orientation [4]. Obviously, the competence and performance requirements that enterprises bring to the attention of their employees have made employability an issue of concern for all solar enterprises and every employee.

As pointed out in competence-based theory, the important features of solar industry employability are the emphasis on advancing competence by individuals and, in particular, a focus on the advancement of competence in long-term self-career development embarked upon by engineers. Therefore, this research aims to answer the following questions: what job performance skills are graduates of universities of technology from solar energy-related departments required to demonstrate by employers and how should these skills be reflected in major student employability indicators? The major contribution of these indicators in the solar industry would be for the selection of talent in recruitment and as a reference for the internal cultivation of talent and for onthe-job training, while in engineering education, they would 
provide a basis for the planning and design of the solar energy curriculum, enhancing university students' employability $[5,7]$.

Accordingly, the research focused on what is required for students who have been employed in the solar industry to sustain long-term employment there, translating these job performance requirements of the workplace via qualitative research methods into employability indicators $[8,9]$, as well as confirming the applicability of the employability indicators through a qualitative survey and analysis [10]. Thus the purpose of the research was to establish a set of employability indicators for students contemplating employment in the solar industry after graduation from universities of technology. The aim was that the indicators would represent the performance that solar industry enterprises expected students to demonstrate in their future job positions in ways that made the demands of such jobs painfully obvious. From which starting point, the research desired to establish a competence and performance interpretation model for the selection of talent by enterprise recruiters and for reference by internal solar enterprise talent cultivation planners. With these goals, the role of and implications for curricular planning in engineering education take on clearer shape. The research's primary contribution to theory is the establishing of an interpretation model for the relationship between competence, job performance, working attitudes, and employability, by means of the establishment of employability indicators in the solar industry.

\section{Employability}

Employability is generally recognised as the ability of a student to successfully apply for employment after graduation in a smooth way, to maintain their long-term prospects for similarly acquired positions and to develop their job careers favourably over the remainder of their working lives [11]. Cox and King [12] consider employability to signify a person's possession of the ability to acquire skills for the implementation of required jobs, indicating that employability does not necessarily mean a person could start working immediately without further training. Employability can be deemed to be a special feature of a person's capability for work and the desire to maintain his or her attractiveness in the labour market [13]. Hillage and Pollard [14] assume "employability" to mean that the individual could self-sufficiently realise his or her potential for employment in the labour market and continue to demonstrate self-sufficiency in his or her work position even when there are limited job resources. Pool and Sewell [15] believe that employability could be understood as its embodiment in an individual who possesses a set of skills, knowledge, and ability to develop satisfactorily and successfully in the employment market. Rothwell and Arnold [2] deem from the point of view of an individual's employment and career development that employability is concerned with long-term career development in professional fields, even to the point of inclusion of the capability to shift into different professions [16]. In this view, the essence of employability can even be seen as the capability of an individual to shift into another profession for employment after the employment market of the individual's professional field is saturated. Hence, employability also emphasises the possession of a good profession spill-over effect. On the basis of these definitions, this paper defines employability in the domain of the solar industry as the embodiment in an individual of the capability to maintain the ongoing acquisition of knowledge, skills, and positive attitudes and to properly translate learning experiences into such forms, so as to maintain demonstrations of the performances expected by enterprises on being employed. Persons with high employability potential can learn fast when they are asked to execute a task demanded by a job, and they can transform personal knowledge and skills into the expected job performance according to the job scenario's requirements of the solar industry.

2.1. Diverse Point of View of Employability. Three different aspects, input, process, and result, afford different views on employability, contributing to the direction of research.

(i) The input point of view, which sets out from the point of view of structuralism to explore the composition of employability, based on competence-based theory, considers that an individual must possess good competence to be able to demonstrate high performance on the job. Such researchers as Hafeez and Essmail [17], Peng [18], and Rae [1] demonstrate this point of view.

Research results based on competence-based performance theory are emerging [19]. Robbins [20] assumes that performance measurement based on competence could include individual job output, behaviour, and personal characteristics (including the exhibition of attitudes, self-confidence, independence, cooperation, experience, and others related to superb job performance). Competence-based theory has done well explaining the reference criteria adopted by modern enterprises for recruitment, so graduates need to possess the competences required by the employment market.

(ii) The process point of view, which emphasizes a high level of association between school curricula and the employment market, considers it necessary to reflect enterprise experts' expectations of students in curricular design and learning activities. School subjects should maintain focus on the changes in practical needs [21]. Rae [1] believes that the students' experience of learning core subjects should be associated with enterprises and employability.

(iii) The result point of view, which takes the point of view of behaviourism and follows resource-based theory exploring the demonstration of employability, translates performance standards required by the working world into the job performances expected by enterprises, by, for example, the empirical investigation of resource-driven performance conducted by Fernandes et al. [22]. 
Resource-based theory considers the three elements, company-critical resources, capabilities and competencies to be associated concepts [23], where capabilities and competencies are considered to be interchangeable [24]. The term capabilities was considered by the Ljungquist [25] study to have two meanings, one was the ability of a work team to utilize resources needed in execution of a certain task or activity; the other was an individual's tacit knowledge and organizational memory, which could be incorporated and applied to job coordination. As pointed out in resourcebased theory, enterprises expect graduates who are devoted to the workplace to demonstrate good ability in integrative planning and the disposal of available resources. Therefore this research took its direction from the result point of view on employability and emphasized job performance standards to be decided according to the enterprise workplace's surroundings, coupled with experts' judgment, developing the requirements for students' employability in solar enterprises.

2.2. Employability Indicators. Employability indicators from the performance point of view naturally put emphasis on job performance. So-called job performance can be defined as the pursuance of special action by a person with the ability to maintain and conform to the condition, policy, and procedure given by the organizational environment to effectively accomplish the job demands [26]. "Job" is considered to be a certain special appointment in the achievement of a certain task, while the task is a description of the activity content of a certain job for an employee [27]. The performance of an employee can include the two categories of job behaviour and activity and job result [28]. The former applies to the job process itself and is assessed mainly by measuring the activity engaged in and the behaviour demonstrated on the job by the employee, while the latter assesses the degree of accomplishment by the employee of a predetermined target. As pointed out by SPSP [29], job performance needs to emphasize ACT, which means the following:

A: employees' effective and timely completion of a job activity;

C: employees' competence to do a good job;

$\mathrm{T}$ : their possession of tools and techniques.

In respect of employability indicators, Table 1 summarizes related studies.

In summary of the above, the logical process for the establishment of draft employability indicators in this research following the performance point of view is

(1) to define the performance point of view of employability;

(2) to obtain "diverse points of view on employability;"

(3) to fold in the path of research from the "result point of view."

For (1), we took the point of view of Ljungquist [25], SPSP [29], Chang [5, 30], and Kuo and Sheen [31] and decided performance-point-of-view employability to be on-the-job integrated planning, evaluation and judgment, working efficiency, working quality, working spirit, monitoring control, and working attitude.

Based on the needs of the research, the operational definitions for each indicator are as shown in Table 2.

\section{Methodology}

The study adopted field interviews and meetings with focus groups as its qualitative methods, while a questionnaire survey provided data for its quantitative methods.

3.1. Field Interviews. The field interviews were conducted with 12 administrators (see Table 3 ) from solar enterprises throughout Taiwan and with 32 of the top-10\%, highperforming workers. All interviews were completed within a 5 -month period. The interview form used in this study followed Dessler's methods [32] for the collection of duties for graduates' first employment in solar enterprises, where the STAR specific behavioural events included (1) situation: the circumstance surrounding an incident; (2) task: the target generated in response to the demands of the situation; (3) action: the behaviour exhibited by the person in charge; and (4) result: the outcome of the action. The Behavioural Event Interview (BEI) method was applied in translating the behavioural events into the questionnaire items.

Key points in the STAR-specific behavioural event interview included the listing of each STAR item with emphasis on the response a good performance worker should exhibit for each supposed demonstrative behavioural feature, the degree of improvement through training, the possibility to make up a performance insufficiency via recruiting new employees, the capacity standard (certificate requirement) needed by individuals, and the suggestion for measures when the individual's competence is inadequate to demonstrate the anticipated performance (see Tables 4 and 5).

3.2. Focus Group Method. A group was formed of 12 experts, amongst whom were a manpower resources consultant and specialists from industry and academia. Focus group meetings were held with the participation of the consultant, general manager, marketing plan manager, manpower resources department staff representatives, department heads, managers, scholars, and high-performing workers. In the process of the group's repeated discussion, the draft questionnaire that originally contained 110 questions was modified and combined to formulate the final questionnaire with 37 questions. The structure of the questionnaire is shown in Table 6.

3.3. Survey Research. Through analysis by the experts of the focus group, the draft questionnaire was tested for its reliability and overall validity. Cronbach's $\alpha$ coefficient was used to examine the internal consistency of responses from pretest receivers. The content validity of the test was assessed through the confirmation of the employability indicators by the focus group and systematic examination of the questionnaire content to determine whether the questionnaire did fully reflect the practical behaviours represented by the 
TABLE 1: Related studies of students' employability in engineering education.

\begin{tabular}{|c|c|}
\hline Experts/institution & Employability indicators \\
\hline Tsai et al. [28] & Work attitude and job performance are closely related. \\
\hline Kagaari [33] & $\begin{array}{l}\text { Application of skills, responsibilities, challenges, creativity, originality, safety, career development, } \\
\text { adaptation to status quo, technical knowledge at work, and so forth. }\end{array}$ \\
\hline MOE $[34]$ & $\begin{array}{l}\text { The most needed to enhance employability: foreign language ability, job searching and } \\
\text { self-promoting capacity, innovation capability, and leadership capacity. }\end{array}$ \\
\hline NTNU [35] & $\begin{array}{l}\text { Core employability: working attitude and cooperation capacity favourable for employment, } \\
\text { occupational career planning capacity and aggressive learning to advance, possession of } \\
\text { professional knowledge, and ability to apply them at work. }\end{array}$ \\
\hline Peng $[18]$ & $\begin{array}{l}\text { (i) Employability is constructed from three elements: capacity, attitude, and confidence. } \\
\text { (ii) Detailed indicators: presentation and communication skills, teamwork cooperation, mother } \\
\text { tongue language capability, stability or stress resistance, professional knowledge and techniques, } \\
\text { basic computer application skills, the ability to explore and solve problems confronted at work, } \\
\text { good working attitudes, strong willingness to continue with studies, high degree of plasticity, } \\
\text { professional ethics and morality, optimism in facing career development prospects, active } \\
\text { dedication to current job, leadership capacity, innovation capacity, the capacity to apply theory to } \\
\text { actual work, professional certificates or related capacities, knowledge of the relevant industrial } \\
\text { environment and its development status, foreign language capacity, full understanding and } \\
\text { planning for self-career development, and possession of job searching and self-promoting } \\
\text { capacity. }\end{array}$ \\
\hline NTNU [35] & $\begin{array}{l}\text { A } 2005 \text { follow-up survey of university graduates after one year of employment found } \\
\text { insufficiencies in employability and concluded the causes to be lack of leadership capacity, } \\
\text { innovation capacity, the capacity to apply theory to actual work, professional certificates or related } \\
\text { capacities, knowledge of the relevant industrial environment and its development status, foreign } \\
\text { language capacity, full understanding and planning for self-career development, and possession of } \\
\text { job searching and self-promoting capacity. }\end{array}$ \\
\hline Jaffer et al. [36] & Efficiency and quality are the challenges of industry for advanced education. \\
\hline Kuo et al. [37] & $\begin{array}{l}\text { Four common dynamic capabilities in response to external demands: "market-oriented } \\
\text { sensitivity," "the ability to absorb knowledge," "social-networking capability," and "the integrative } \\
\text { ability to communicate and negotiate." Three special dynamic capabilities required by business } \\
\text { practices: "the capability to identify what drives market growth," "the capability to develop a good } \\
\text { sense of market-entry timing," and "the capability to alter/create customers' needs." }\end{array}$ \\
\hline Chang $[30]$ & $\begin{array}{l}\text { Market-oriented sensitivity, the ability to absorb knowledge, social-networking capability, and the } \\
\text { integrative ability to communicate and negotiate are the dynamic capabilities required of IT } \\
\text { entrepreneurs. }\end{array}$ \\
\hline
\end{tabular}

employability indicators. Afterwards, Bartlett's sphericity test was applied to confirm whether each aspect was near normal multivariate, and the KMO (Kaiser-Meyer-Olkin) measure of sampling adequacy was adopted for the factor validity test to determine whether factor analysis was appropriate or not. Finally, the major step of content analysis was performed, conducting oblique rotation for maximum variance of the factors revealed by the factor analysis with the intent of assessing the validity of the construction of the questionnaire and the order of importance of the employability indicators.

Random sampling of small and medium solar enterprises in the Taiwan area for the addressing of a survey with the internet version of the questionnaire was the method adopted for data collection. After removing repeated mailings of the questionnaire returned, a total of 501 valid returns were received representing a response rate of $50.1 \%$. The purpose of analysing the data was to understand whether the employability indicators established by the research could receive popular recognition from the solar energy industry.
The application of the above mentioned research methods followed the logical procedure listed below, with a research result being associated with each of the different stages:

(i) literature analysis: to obtain key points for field interviews;

(ii) focus group meetings I: to confirm key points for field interviews via experts' points of view;

(iii) behavioural events interview method: to obtain the draft employability indicators from the performance point of view;

(iv) focus group meetings II: to confirm the draft employability indicators and the draft questionnaire;

(v) implementation of survey and data analysis. Following this procedure, several meetings were held during Stage II of the focus group process due to diverging opinions from experts on the significance of the employability indicators. It was considered that 
TABLE 2: The definition of employability indicators in the solar industry.

\begin{tabular}{ll}
\hline Indicators & Operational definitions \\
\hline Integrated planning & $\begin{array}{l}\text { To do project planning and implementation with the ability to consider the project's marketability, } \\
\text { executability, and effectiveness, so as to further integrate resources in generating the maximum } \\
\text { value for the company and customers. }\end{array}$ \\
\hline $\begin{array}{l}\text { Evaluation and } \\
\text { judgment }\end{array}$ & $\begin{array}{l}\text { To execute difficult work with the ability to conduct prior assessments and find the best work } \\
\text { procedures, methods and possible supporting resources within the company. }\end{array}$ \\
\hline Working efficiency & $\begin{array}{l}\text { To execute work with the capacity for self-adjustment, active acquisition of new knowledge and } \\
\text { techniques, goal-oriented work, advanced completion according to quality requirements, finding } \\
\text { problems, and finding the right person to do the thing right. }\end{array}$ \\
\hline Working quality & $\begin{array}{l}\text { To ensure that quality is the priority for the completion of work content, with the ability to fully } \\
\text { control each factor in a workflow, with self-inspection exhibiting a high level of quality of work } \\
\text { results. }\end{array}$ \\
\hline Working spirit & $\begin{array}{l}\text { To accept challenging work targets, focus attention, make good use of strategies, manage } \\
\text { resources, and finish job tasks on time. }\end{array}$ \\
\hline Monitoring control & $\begin{array}{l}\text { To observe cost control and work progress control, put emphasis on process monitoring and } \\
\text { control, eliminate potential interfering factors, and present satisfactory work results to } \\
\text { supervisors. }\end{array}$ \\
\hline Working attitude & $\begin{array}{l}\text { To be proactive, active, and aggressive without the need for others to urge or remind, have great } \\
\text { ambition and willingness to take on jobs and help colleagues actively, have good relationships } \\
\text { with people stemming from a positive attitude towards others, and exhibit work results surpassing } \\
\text { supervisors' expectations. }\end{array}$ \\
\hline
\end{tabular}

TABLE 3: Taiwanese solar product manufacturers sampled and interviewed in this study.

\begin{tabular}{|c|c|c|c|c|}
\hline $\begin{array}{l}\text { Manufacturers' } \\
\text { positions in the } \\
\text { supply chain }\end{array}$ & Chief products & $\begin{array}{c}\text { Number of companies } \\
\text { sampled }\end{array}$ & Percentage (\%) & $\begin{array}{c}\text { Number of companies } \\
\text { interviewed (\%) }\end{array}$ \\
\hline Upper-stream firms & $\begin{array}{l}\text { Silica materials, silicon } \\
\text { wafer materials }\end{array}$ & 17 & 13.93 & $3(25 \%)$ \\
\hline \multirow[t]{6}{*}{ Mid-stream firms } & & 47 & 38.51 & $4(33.33 \%)$ \\
\hline & Solar cells & 15 & 12.30 & \\
\hline & Solar cell modules & 18 & 14.73 & \\
\hline & $\begin{array}{l}\text { Thin-film solar cell } \\
\text { modules }\end{array}$ & 9 & 7.38 & \\
\hline & Dye-sensitized solar cells & 3 & 2.46 & \\
\hline & $\begin{array}{l}\text { Concentrator solar cell } \\
\text { modules }\end{array}$ & 2 & 1.64 & \\
\hline \multirow[t]{4}{*}{ Lower-stream firms } & & 58 & 47.56 & $5(41.67 \%)$ \\
\hline & Solar photovoltaic system & 39 & 31.98 & \\
\hline & $\begin{array}{l}\text { Solar photovoltaic } \\
\text { converters }\end{array}$ & 10 & 8.20 & \\
\hline & $\begin{array}{l}\text { Sales channels/suppliers of } \\
\text { solar photovoltaic products }\end{array}$ & 9 & 7.38 & \\
\hline Total & & 122 & 100 & $12(100 \%)$ \\
\hline
\end{tabular}

Source: $[37,38]$.

TABLE 4: Structure of field interviews with administrators and good performance engineers (form I).

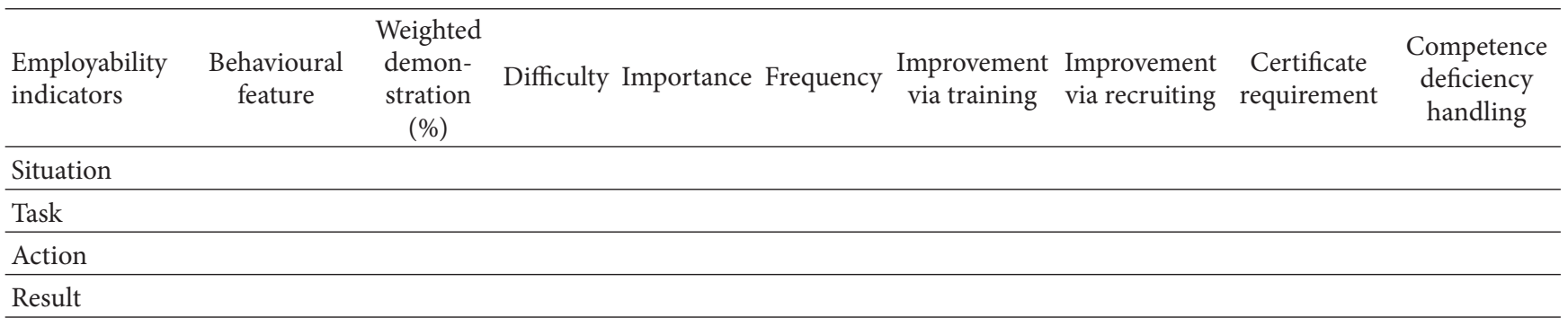


TABLE 5: Structure of field interviews with administrators and good performance engineers (form II).

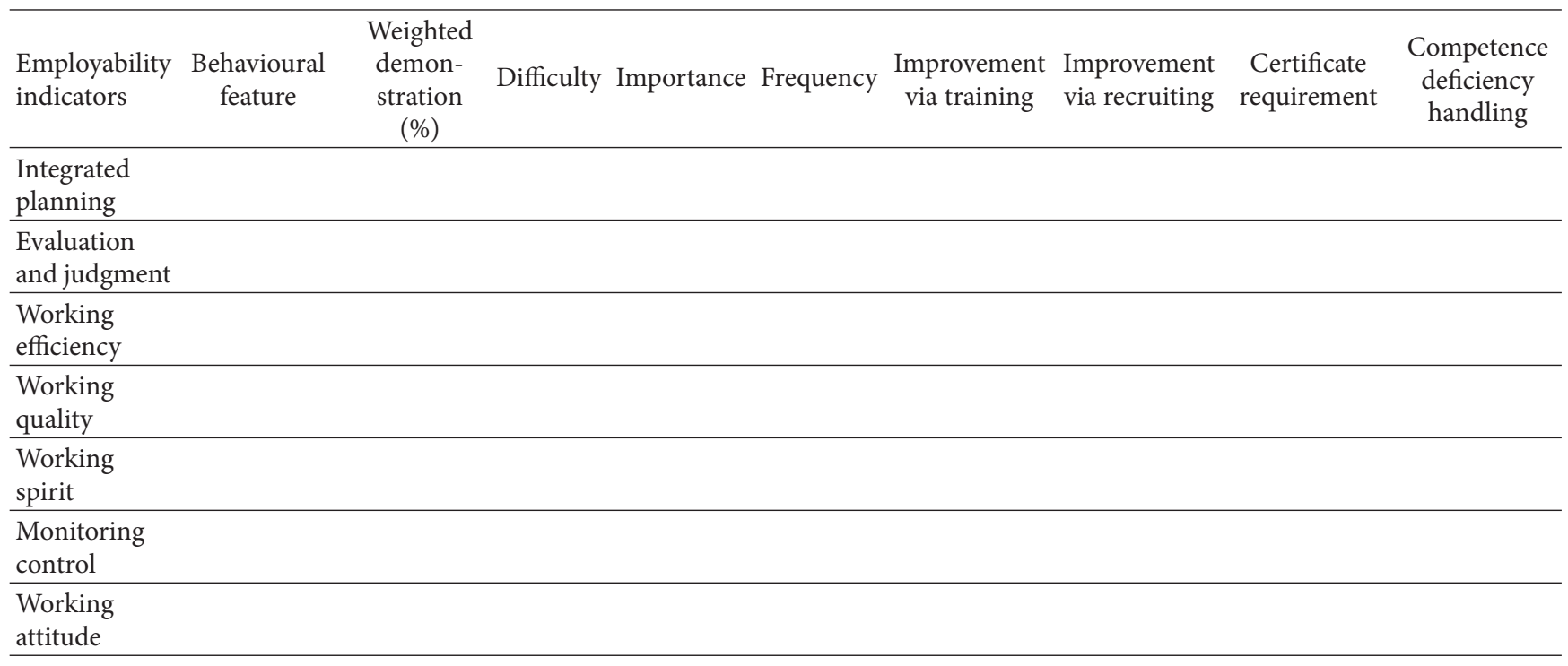

TABLE 6: Structure of the employability survey questionnaire.

\begin{tabular}{|c|c|c|}
\hline & Construct & $\begin{array}{c}\text { Number of } \\
\text { questions for } \\
\text { behavioural event }\end{array}$ \\
\hline \multirow{7}{*}{$\begin{array}{l}\text { Employability } \\
\text { indicators from } \\
\text { performance point of } \\
\text { view }\end{array}$} & Integrated planning & 4 \\
\hline & $\begin{array}{l}\text { Evaluation and } \\
\text { judgment }\end{array}$ & 4 \\
\hline & Working efficiency & 8 \\
\hline & Working quality & 4 \\
\hline & Working spirit & 6 \\
\hline & Monitoring control & 5 \\
\hline & Working attitude & 6 \\
\hline
\end{tabular}

such large differences existed in the direct performance requirements of solar enterprises in manufacturing and services that it was not appropriate to directly translate the direct performance indicators for employees into requirements for students' employability. Therefore, the direct performance requirements for field interviews were transformed to become indirect requirements so that they could represent enterprises' expectations for performance as they affected employability.

\section{Results and Discussion}

4.1. Working Attitudes, Competence, Job Performance, and Employability Form an Interactional Model. The research used competence-based theory to explore performance standards expected to be demonstrated through field interviews with solar industry representatives in order to formulate seven employability indicators that included working attitude, working efficiency, integrated planning, working spirit, evaluation and judgment, monitoring control, and working

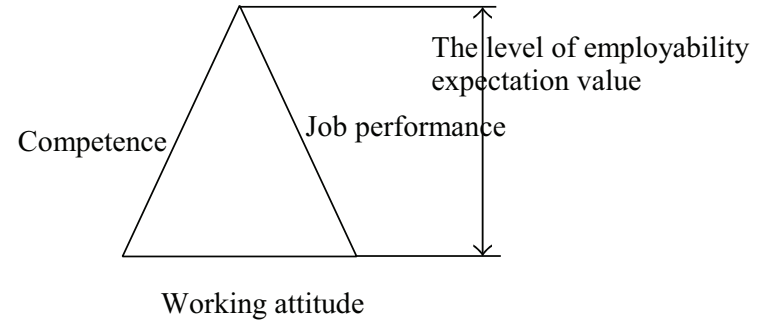

FIGURE 1: Standard competence, job performance, and working attitude.

quality. A triangle shaped interpretation model can be used to summarize the research results. This triangle model is jointly constructed by competence, job performance, and working attitude, where the combination of the mutually dependent competence and job performance determines the expected value of students' employability in the industry. The concept is shown in Figure 1. From the results of field interviews, it was seen that "working attitude" establishes a basis upon which an employee can fully express his or her competence and demonstrate the "job performance" expected by the company. Employability demonstrates consistency between the level of an individual's "competence" and "job performance;" these two also contribute to high employability, in the form of the individual's long-term value for the company. The implications include the following (as in Figure 2).

(i) Working attitude and competence and job performance together form an interactional model. The height of the triangle signifies employability in the long term for the individual in the enterprise.

(ii) Variation in employability is based on working attitude, and working attitude determines the level demonstrated in competence and job performance in the enterprise. 


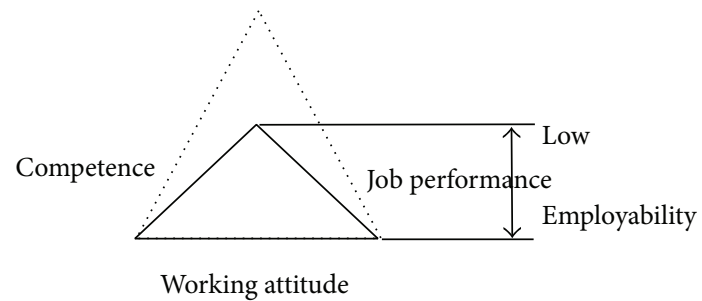

Figure 2: Work attitude determines the level of competence and job performance.

(iii) There is interdependence between competence and job performance, where engineers who possess competence can demonstrate the expected job performance in the enterprise.

(iv) As a result of problems in the enterprise's internal organizational behaviour, employees with high competence might not necessarily demonstrate high job performance. However, the possession of a superior working attitude may compensate for such a condition.

(v) Working attitude determines the level of competence and job performance. The possession of an aggressive working attitude and active learning competence can help increase job performance. When an individual's job performance is not as expected, good working attitude could enable the individual to pursue a higher job performance and to improve his/her value for long-term employment by the enterprise.

4.2. The Contribution of Competence Was Augmented and the Performance Requirement Was Diminished. From a crosscomparison of field interview results it was seen that even if the interviewed objectives were screened in advance, the interviewees still exhibited for some of the work items exaggerated opinions of the competencies required. Conversely, they also exhibited for some of the enterprises' job performance requirements weakened expectations. Possible reasons for this may include the following.

(i) Enterprises are generally likely to consider students who are the first to be employed as the ones who are more likely to execute their jobs with the assistance of senior supervisors.

(ii) Enterprises usually consider students' possession of professional certificates as merely establishing the minimum level needed to enter the workplace, with on-the-job training (OJT) more or less still being needed for students to properly qualify for the job.

(iii) The phenomenon of exaggerated expressions, if not truly heightened beliefs, in the requirements of competence could be explained from the expectation theory angle of Chang [5]. The interviewed persons might expect their opinions to be respected by their administrators and thus affect the company's salary adjustment policy.
4.3. The Questionnaire Had Good Reliability and Validity. In the qualitative study, reliability of the questionnaire overall, as measured by Cronbach's $\alpha$, reached a value of 0.927 , indicating that reliability was excellent. The maximum KMO value was 0.838 while the validity of all factors reached a medium $(\mathrm{KMO}>0.7)$ level, indicating the questionnaire data was stable. Meanwhile, the Bartlett value of $869.15(P<0.01)$ also indicated each dimension of the data to be near normal multivariate and suitable for further factor analysis.

Principal component analysis was adopted for the factor analysis, and Promax with Kaiser normalization was performed. For the employability index eigenvalues $>0.7$ were chosen, with factor loadings $>0.6$. The standard for extracted factors was that they should contain at least two items for assessment. The reason for selecting eigenvalues $>0.7$ was to ensure that the goodness-of-fit of the factor model reached an acceptable level and the adoption of the Kaiser method and Scree test to find solutions was feasible. In order to ensure the integrity of the factors, a Scree test was conducted to decide on the number of factors. The analysis results extracted 18 items and 7 factors with the interpretation capability reaching $80.35 \%$ as listed in Table 7 .

The purpose of factor analysis was to examine the construct validity of the questionnaire and to form the basis for judging the order of importance of the employability indicators. The application of factor analysis allowed extraction of common factors between the variables, leaving a less complicated data structure in the end. Through the finding of common factors, the conceptual structure of employability can be said to be confirmed. The factor analysis results showed the questionnaire itself to be of good validity, and the ranking of each employability indicator by eigenvalue, in order of importance from high to low, was integrated planning, working spirit, monitoring control, working attitude, evaluation and judgment, working efficiency, and working quality.

4.4. Description of Statistical Analysis. The valid returns consisted of responses from 338 males (67.5\%), the majority, and 163 females, while the age distribution was $26-30$ (57.5\%), $21-25(21 / 25 \%)$, and $31-35$ (16.25\%). Technical duties were the most represented $(71.8 \%)$ among the duties surveyed, as listed in Table 8, while seniority from 3 years to less than 5 years (41.0\%) was most common, as listed in Table 9. Averages and standard deviations for different categories are shown in the Table 10.

Observation of the individual average of each employability indicator shows the three items: working spirit, evaluation and judgment, and working quality to be significantly higher. It is possible that as a result of the fact that a large majority of the survey respondents had technical duties as their responsibility, these three items were particularly emphasized.

4.5. The Radar Chart Indicates the Level of Employability Required by Enterprises for Students of Solar Technology. The purpose of the radar chart is to help understand whether the questionnaire survey results indicate that enterprises regard a score of 60 percent for university students' employability 
TABLE 7: Employability indicators factor analysis.

\begin{tabular}{|c|c|c|c|c|c|c|c|}
\hline $\begin{array}{l}\text { Number of } \\
\text { questions }\end{array}$ & Integrated planning & Working spirit & $\begin{array}{c}\text { Monitoring } \\
\text { control }\end{array}$ & Working attitude & $\begin{array}{l}\text { Evaluation } \\
\text { and } \\
\text { judgment }\end{array}$ & Working efficiency & $\begin{array}{c}\text { Working } \\
\text { quality }\end{array}$ \\
\hline $\mathrm{A} 2$ & 0.94 & & & & & & \\
\hline $\mathrm{A} 1$ & 0.93 & & & & & & \\
\hline A3 & 0.86 & & & & & & \\
\hline A4 & 0.79 & & & & & & \\
\hline A26 & & 0.83 & & & & & \\
\hline A 25 & & 0.83 & & & & & \\
\hline A 27 & & 0.71 & & & & & \\
\hline A14 & & & 0.87 & & & & \\
\hline $\mathrm{A} 28$ & & & 0.86 & & & & \\
\hline A36 & & & & 0.92 & & & \\
\hline A35 & & & & 0.89 & & & \\
\hline A8 & & & & & 0.87 & & \\
\hline A7 & & & & & 0.86 & & \\
\hline $\mathrm{A} 24$ & & & & & & 0.81 & \\
\hline $\mathrm{A} 12$ & & & & & & 0.76 & \\
\hline A15 & & & & & & 0.72 & \\
\hline A20 & & & & & & & 0.94 \\
\hline A 33 & & & & & & & 0.65 \\
\hline Eigenvalue & 7.95 & 1.93 & 1.21 & 0.95 & 0.90 & 0.78 & 0.75 \\
\hline $\begin{array}{l}\text { Descriptive } \\
\text { variation }\end{array}$ & $44.19 \%$ & $10.71 \%$ & $6.70 \%$ & $5.29 \%$ & $4.99 \%$ & $4.33 \%$ & $4.14 \%$ \\
\hline $\begin{array}{l}\text { Accumulative } \\
\text { descriptive } \\
\text { variation } \\
\text { value }\end{array}$ & $44.19 \%$ & $54.90 \%$ & $61.60 \%$ & $66.89 \%$ & $71.88 \%$ & $76.21 \%$ & $80.35 \%$ \\
\hline
\end{tabular}

Factor extraction: principal component analysis.

Rotation method: Promax with Kaiser normalization.

TABLE 8: Distribution of respondent duties $N=501$.

\begin{tabular}{lcc}
\hline Valid & $\%$ & Accumulated \% \\
\hline Sales duties & 5.1 & 5.1 \\
Technical duties & 71.8 & 76.9 \\
Management duties & 5.1 & 82.1 \\
Administrative duties & 7.7 & 89.7 \\
Others & 10.3 & 100.0 \\
\hline Total & 100.0 & \\
\hline
\end{tabular}

TABLE 9: Distribution of respondent seniority $N=501$.

\begin{tabular}{lcc}
\hline Valid & $\%$ & Accumulated \% \\
\hline less than 1 year & 5.1 & 5.1 \\
1 year to less than 3 years & 20.5 & 25.6 \\
3 years to less than 5 years & 41.0 & 66.7 \\
5 years to less than 10 years & 23.1 & 89.7 \\
over 10 years & 10.3 & 100.0 \\
\hline Total & 100.0 & \\
\hline
\end{tabular}

as a generally acceptable level. The degree of employability expected by solar enterprises, as measured by the responses to the indicator questions in the survey, were plotted according to the average for each indicator to form the radar chart as shown in Figure 3. Assuming that the weighted value for each factor is the same and taking level 5 from the questionnaire scale as the highest and 1 as the lowest, then a triangle can be formed between any two factors. The ratio method was applied to calculate the area of the included angle between the two factors $(\Delta)$ with the equation $\Delta=(1 / 2) a b \sin \theta$, where $a, b$ represent the 2 arm lengths (e.g., for the $\Delta 1$ area calculation where $a=3.26, b=3.84$ ) [11]. Hence, the level of employability is $\sum \Delta_{i}=92.20$ in comparison to the ideal value $\sum \Delta=150$ (i.e., the two arms $a=5$ and $b=5$ ) and so a value of $61.47 \%$ after being expressed as a percentage. This indicates that the individual enterprise workers who took the survey considered a score of about 60 to be an acceptable level for the employability that students of solar technology should be required to demonstrate.

As indicated by the radar chart analysis of each employability indicator, the averages obtained from the survey on 
TABLE 10: Averages and standard deviations of job performance indicators.

\begin{tabular}{|c|c|c|c|c|c|}
\hline Category & Indicator & $\begin{array}{l}\text { Individual } \\
\text { average }\end{array}$ & $\begin{array}{c}\text { Individual } \\
\text { standard } \\
\text { deviation }\end{array}$ & Average & Standard deviation \\
\hline \multirow{7}{*}{$\begin{array}{l}\text { Employability } \\
\text { indicators from } \\
\text { performance point of } \\
\text { view }\end{array}$} & Integrated planning & 3.26 & 0.93 & \multirow{7}{*}{3.60} & \multirow{7}{*}{0.57} \\
\hline & Working spirit & 3.70 & 0.70 & & \\
\hline & Monitoring control & 3.54 & 0.67 & & \\
\hline & Working attitude & 3.60 & 0.84 & & \\
\hline & $\begin{array}{l}\text { Evaluation and } \\
\text { judgment }\end{array}$ & 3.84 & 0.69 & & \\
\hline & Working efficiency & 3.68 & 0.61 & & \\
\hline & Working quality & 3.79 & 0.68 & & \\
\hline
\end{tabular}



\begin{tabular}{|cc|}
\hline Zone $\Delta$ & Area \\
\hline$\Delta 1$ & 12.52 \\
$\Delta 2$ & 14.13 \\
$\Delta 3$ & 13.95 \\
$\Delta 4$ & 14.02 \\
$\Delta 5$ & 13.10 \\
$\Delta 6$ & 12.74 \\
$\Delta 7$ & 11.74 \\
\hline Total area & $\sum \Delta_{i}=92.20$ \\
\hline
\end{tabular}

FIgURE 3: Area of employability expected by individual workers to be demonstrated.

the Likert scale were all over the level of 3 (e.g., 3.26 for integrated planning). However, from conversions of the radar chart areas, we see that the industry responders did not hold very high levels of expectation for students' performance. This implies that enterprises require students' employability at only the minimum level and emphasize the formation of employees' competence and working attitudes after their entry into the workforce.

\section{Conclusions}

The procedure this study followed to obtain its seven employability indicators was to take the concept of key performance indicators (KPI) and infer an application to the employability of students of universities of technology. The research process was essentially competence-based and as such was meant to achieve the goal of estimating competence from performance. The interpretation model, relating competence, job performance, working attitude, and employability, allows for effective interpretations of the relationship between enterprises' expectations and students' employability. In addition, the fact that the development of the employability indicators came from the results of field interviews signifies that there is a correspondence between the employability indicators and the short life cycle of Taiwanese solar industry products and the special requirement of the fierce market competition. Meanwhile, each indicator is also appropriate as the basis for curricular planning in solar technology departments of universities in the Taiwan area. In other words, when students possess the employability items named in this research then they shall hopefully be more encouraged to brave the challenge of the ever stricter requirements for long-term employment in the industry.

As for an immediate practical application, enterprises can use the employability indicators to develop an "Employability Assessment Form" that meets the requirement by individual enterprises for the most objective method of recruiting new employees possible. The employability indicators can be further used for planning enterprise-internal training courses to enhance workers' employability in the long term.

Performance assessment can be quite difficult for the industry, which is made up of product manufacturing, service, and technical service businesses whose knowledge requirements and business activities can vary largely. As a result of the depth and broadness of this variation, therefore, each company may expect students to perform differently. 
A limitation of this research is that it only explored "job performance" in terms of its direct relationship with work.

The natural follow-up to this study and the development of the framework are curricular design based on the employability indicators. The seven employability indicators obtained from this research allow the matching of job positions in the solar industry suitable for recent graduates with the planning of courses that keep curriculum enhancement in mind as well as employability. The curriculum could include both the formal curriculum and informal curriculum. The formal curriculum should have a definite goal structure, including employment targeted curriculum, practical training in solar enterprises, and industrial and academic-type optional courses, while the informal curriculum can be based on industrial and academic activities, such as topical lectures, field visits to enterprises, and workplace experiencing. The curriculum should be reviewed periodically by experts invited directly from industry in order to ensure that the design of the curriculum corresponds to the requirements described in the employability indicators.

\section{Conflict of Interests}

The authors declare that there is no conflict of interests regarding the publication of this paper.

\section{References}

[1] D. Rae, "Connecting enterprise and graduate employability: challenges to the higher education culture and curriculum?" Education and Training, vol. 49, no. 8-9, pp. 605-619, 2007.

[2] A. Rothwell and J. Arnold, "Self-perceived employability: development and validation of a scale," Personnel Review, vol. 36, no. 1, pp. 23-41, 2007.

[3] A. Shahin and M. A. Mahbod, "Prioritization of key performance indicators: an integration of analytical hierarchy process and goal setting," International Journal of Productivity and Performance Management, vol. 56, no. 3, pp. 226-240, 2007.

[4] C. C. Chang, "Fuzzy assessment of core competence for human resources in a representative technological organization," NTU Management Review, vol. 18, no. 2, pp. 105-132, 2008.

[5] C. C. Chang, "Obtaining IT competencies for curricular development using Q-technique," International Journal of Academic Research in Business and Social Sciences, vol. 4, no. 3, pp. 60-74, 2014.

[6] D. Lei and J. W. Slocum, "Global strategy, competence-building and strategic alliances," California Management Review, vol. 35, no. 1, pp. 81-97, 1992.

[7] C. G. Kuo and C. C. Chang, "Building professional competencies indices in the solar energy industry for the engineering education curriculum," International Journal of Photoenergy, vol. 2014, Article ID 963291, 6 pages, 2014.

[8] C. G. Kuo, C. Y. Hsu, S. S. Wang, and D. C. Wen, "Photocatalytic characteristics of TiO 2 films deposited by magnetron sputtering on polycarbonate at room temperature," Applied Surface Science, vol. 258, no. 18, pp. 6952-6957, 2012.

[9] C. G. Kuo, C. F. Yang, L. R. Hwang, and J. S. Huang, "Effects of titanium oxide nanotube arrays with different lengths on the characteristics of dye-sensitized solar cells," International
Journal of Photoenergy, vol. 2013, Article ID 650973, 6 pages, 2013.

[10] C. C. Chang, "Building an approach to evaluate capabilities development," Pensee Journal, vol. 76, no. 1, pp. 167-179, 2014.

[11] C. C. Chang, "Improving employment services management using IPA technique," Expert Systems with Applications, vol. 40, no. 17, pp. 6948-6954, 2013.

[12] S. Cox and D. King, "Skill sets: an approach to embed employability in course design," Education and Training, vol. 48, no. 4, pp. 262-274, 2006.

[13] J. Sanders and A. De Grip, "Training, task flexibility and the employability of low-skilled workers," International Journal of Manpower, vol. 25, no. 1, pp. 73-140, 2004.

[14] J. Hillage and E. Pollard, "Employability: developing a framework for policy analysis," Research Report RR85, Institute for Employment Studies, DfEE, Brighton, UK, 1998.

[15] L. D. Pool and P. Sewell, "The key to employability: developing a practical model of graduate employability," Education and Training, vol. 49, no. 4, pp. 277-289, 2007.

[16] R. Z. Wang, "The new evaluative indicator for universityemployability," 2008, http://epaper.heeact.edu.tw/archive/2008/ 09/01/723.aspx.

[17] K. Hafeez and E. A. Essmail, "Evaluating organization core competence and associated personal competencies using analytical hierarchy process," Management Research News, vol. 30, no. 8, pp. 530-547, 2007.

[18] S. M. Peng, "A year after graduating from university survey report," 2008, http://www.cher.ntnu.edu.tw/wp-content/ uploads/file/report/report_94_pba.pdf.

[19] D. D. Dubois, "Competence-based performance improvement: a strategy for organizational change," 2007, http://www .knowledge.hut.fi/projects/itss/referDubois.pdf.

[20] S. P. Robbins, Essentials of Organizational Behavior, Prentice Hall, New Jersey, NJ, USA, 6th edition, 2000.

[21] F. J. Landy and J. M. Conte, Work in the 21st Century, McGrawHill Companies, New York, NY, USA, 2004.

[22] B. H. R. Fernandes, J. F. Mills, and M. T. L. Fleury, "Resources that drive performance: an empirical investigation," International Journal of Productivity and Performance Management, vol. 54, no. 5-6, pp. 340-354, 2005.

[23] G. Hamel and C. K. Prahalad, "Corporate imagination and expeditionary marketing," Harvard Business Review, vol. 69, no. 4, pp. 81-92, 1991.

[24] Y. E. Spanos and G. Prastacos, "Understanding organizational capabilities: towards a conceptual framework," Journal of Knowledge Management, vol. 8, no. 3, pp. 31-43, 2004.

[25] U. Ljungquist, "Core competency beyond identification: presentation of a model," Management Decision, vol. 45, no. 3, pp. 393402, 2007.

[26] D. Boyatzis, The Competence Manager: A Model for Effective Performance, John Wiley \& Son, New York, NY, USA, 1982.

[27] R. A. Noe, Employee Training and Development, McGrawHill/Irwin, Singapore, 3rd edition, 2005.

[28] M. C. Tsai, Q. S. Zheng, and J. H. Lee, "A study on the competence and job performance of the Mainland China direct employees-In case of Taiwanese enterprises of component parts of monitors," Business Review, vol. 10, no. 1, pp. 53-74, 2005.

[29] Success Performance Solutions, "Success performance solutions-Hire competence with confidence," 2009, http://www .super-solutions.com/criteriaone.sap. 
[30] C. C. Chang, "Exploring IT entrepreneurs'dynamic capabilities using Q-technique," Industrial Management and Data Systems, vol. 112, no. 8, pp. 1201-1216, 2012.

[31] C. G. Kuo and B. J. Sheen, "Seaweed chlorophyll on the lightelectron efficiency of DSSC," Journal of the Chinese Chemical Society, vol. 58, no. 2, pp. 186-190, 2011.

[32] G. Dessler, Human Resource Management, Prentice Hall, New York, NY, USA, 11th edition, 2007.

[33] J. R. K. Kagaari, "Evaluation of the effects of vocational choice and practical training on students'employability," Journal of European Industrial Training, vol. 31, no. 6, pp. 449-471, 2007.

[34] Ministry of Education, "Constructing a mechanism of supply chain and integration for high level talents-grasping the flow of university graduates," 2009, http://www.edu.tw/high/ news.aspx?news_sn=2513.

[35] National Taiwan Normal University, "Integrated highereducation database system in Taiwan," 2009, http://www.cher.ntnu .edu.tw/sindex.php.

[36] S. Jaffer, D. N'gambi, and L. Czerniewicz, "The role of ICTs in higher education in South Africa: one strategy for addressing teaching and learning challenges," International Journal of Education and Development Using Information and Communication Technology, vol. 3, no. 4, pp. 131-142, 2007.

[37] C. G. Kuo, C. F. Yang, M. J. Kao et al., "An analysis and research on the transmission ratio of dye sensitized solar cell photoelectrodes by using different etching process," International Journal of Photoenergy, vol. 2013, Article ID 151973, 8 pages, 2013.

[38] IDBMEA, "Industrial Development Bureau, Ministry of Economic Affairs," 2013, http://www.moeaidb.gov.tw/external/view/ tw/inquery/index.html. 

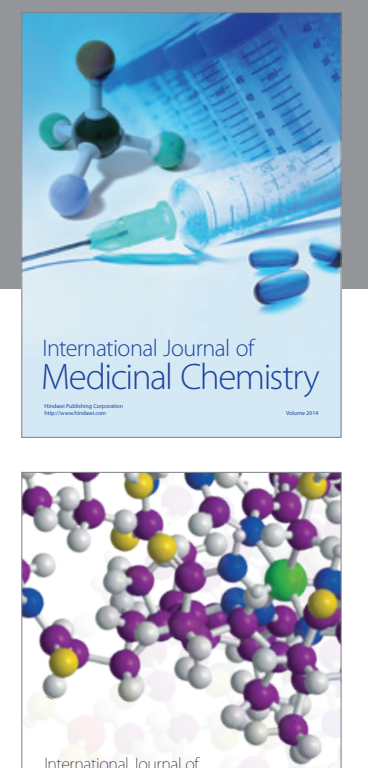

\section{Carbohydrate} Chemistry

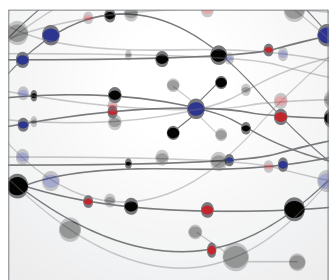

The Scientific World Journal
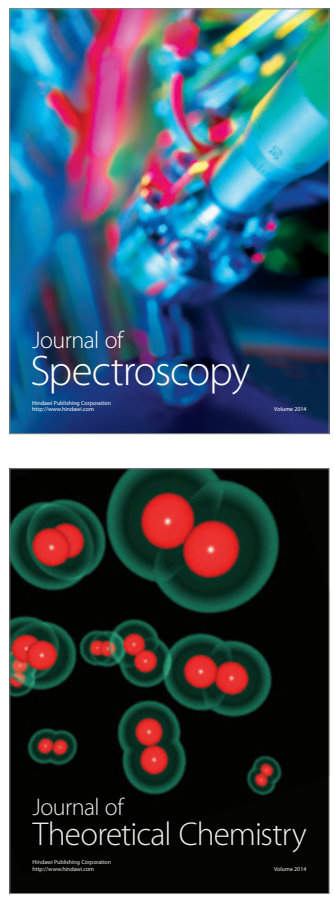
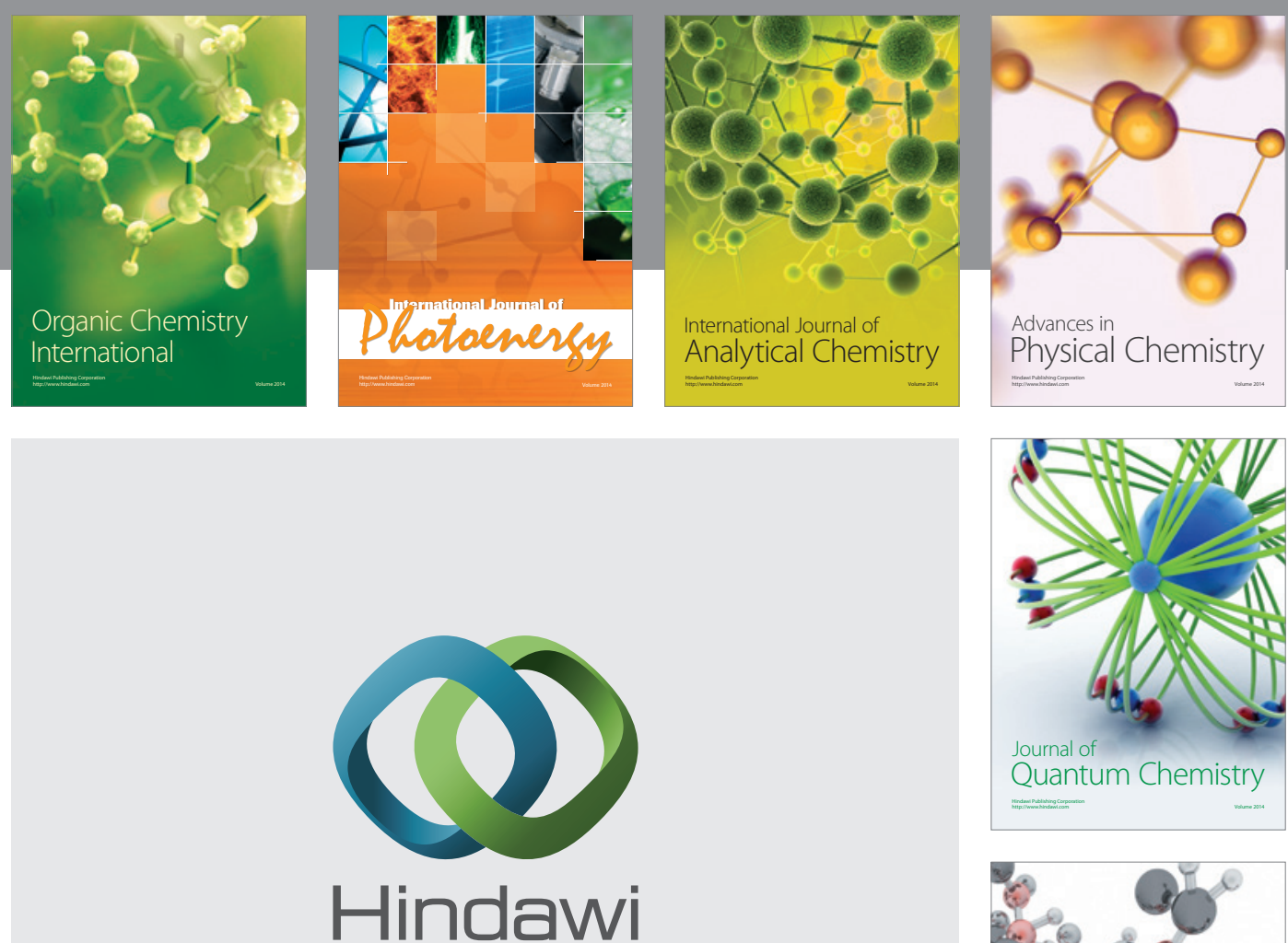

Submit your manuscripts at

http://www.hindawi.com

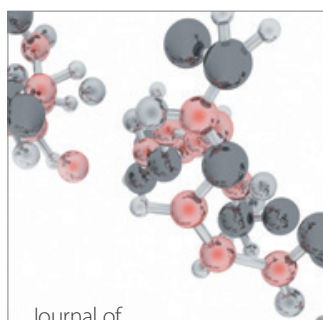

Analytical Methods

in Chemistry



Journal of

Applied Chemistry

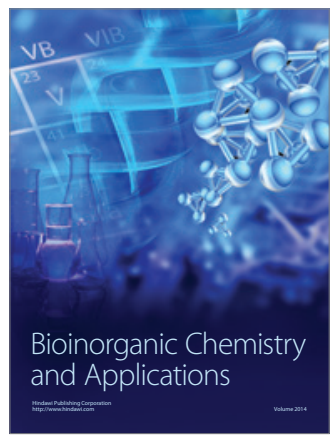

Inorganic Chemistry
